\title{
Women's Anxious Pursuit of Attractive Appearance
}

\author{
Eva A. Szekely \\ Ontario Institute for Studies in Education
}

In this paper, anxious experiencing ${ }^{1}$ as specific to one gender, women, and to a social-historical situation, contemporary North America, are discussed. The focus on women's anxious pursuit of attractive appearance is motivated, in part, by a feminist political agenda. Like all anxious experiences, the pursuit of attractive appearance contains the potential for critical reflection and action. Women's pursuit of attractiveness has not been explored from the perspective of what it can reveal about women's situations and the possible transformations of these situations. When one is living a situation in an anxious manner, one may be impelled to ask questions such as: What kind of existence do I strive for? What sorts of relationships would I like to have with other people? What are my actual relationships like and what are the possible ones? How could the possibilities for alternatives be achieved?

When women resolve anxious experiences by committing themselves to the further pursuit of attractiveness, they may be endorsing projects that have been constructed socially to perpetuate their objectification and exploitation. By such resolutions, critical questions that may lead women to take action other than the pursuit of attractiveness can be avoided momentarily or even for longer periods. Anxiety about whether she can "make" herself attractive takes the place of anxiety about other possibilities concerning the future. By focusing on how the body can be "perfected," issues not related directly and immediately to the beautification of the body may recede into the background. Yet it is precisely the experience of anxiety that may lead women to the question: Why must I produce myself as attractive in the first place? To turn away from this question is to turn away from the possibility of transforming situations in which the pursuit of attractive appearance is a must for women.

This is an issue for all contemporary North American women because not one of us is entirely free from the pursuit of attractive appearance. It seems, in fact, that more and more women are devoting increasing amounts of time to the work of beautification. Unsolicited enticements land on our doorsteps daily, beckoning us to join fitness clubs, suntan studios, weight loss clinics, health spas, and beauty parlors, all of them offering us a more perfect appearance. The implicit message is, of course, that in its present shape the body we have is not good enough. From a position of insecurity and 
necessity, within or beyond their means, with or without feeling guilty, but invariably in an anxious manner, many women respond to the call.

Many women feel they must respond to the call to beautify themselves. They may feel that this one program just might "do it." What might this program-be it weight-loss by dieting and/or exercise, suntan or make-up and color analysis-achieve? Will it make her "feel good," will it make her "happy," will it help her do something? Hidden in all calls for women to join yet another program of beautification is the promise, "you will be more attractive if." It is, of course, not primarily to herself or to other women that she will appear more attractive. Women know, tacitly or explicitly, that attractiveness is the value of currency in the male realm; it is men they must attract.

\section{Bodies as Objects of Men's Desires}

For a woman to be concerned about the body's appearance is to be concerned with the possibility of her future existence. From a temporal perspective, women's pursuit of attractiveness is revealed as women's attempt to have a future. It is this chord-the anxiety about the future-that the call for beautification touches, whether women are consciously aware of their attractiveness being a key to their future existence or not. Women's anxious pursuit of attractive appearance reveals their situations as tied centrally to their relationships with men; their future depends on men as husbands, lovers, employers, bosses, and even co-workers.

The promises on which most women in North America have been raised are attached to a women's ability to attract men, and one man in particular who will marry her. It is through this ability to attract and thus be attached to a particular man that women's lives are presumed to be fulfilled and their continued existence guaranteed. Most women, if they can share in wealth and power at all, can do so primarily by enhancing the potential of their bodies as objects of men's desires. A woman may try to produce herself as attractive to be desirable to a man, to almost any man, who proposes to marry her. For, even today, being married is the condition of women's worth and acceptance; marriage is still considered the natural mode of being a woman. Approximating the ideal of attractiveness opens up for women determinate possibilities that have been necessitated by women's historical and socioeconomic position in our society and made desirable by the commercial media. It is not "natural" that women want to be attractive; the pursuit of attractiveness is not merely a personal preference of choice women make. The necessity for women to be attractive can be understood as power through the body. "The ideal traditional marriage" has been depicted as "just that exchange of her beauty for his wealth, influence and power." 
In conjunction with the economic reasons, marriage has been made desirable to women because it represents the promise of the fulfillment of fantasies such as romantic love and happiness. ${ }^{3}$ Further, marriage signifies to women that they are persons of worth, they are acceptable and accepted; when married, they will have done the "proper thing," that which they have been meant to do all their lives. Not seeing themselves as attractive is intertwined in the lives of women with dreading the possibility of not being able to attract a man for marriage. This means that the opportunity to fulfill the fantasies of romantic love and happiness, acceptance and worth, are lost; she will be "nothing" and "nobody," in one woman's words, if she could not attract men. ${ }^{4}$

The ideology of romantic love and women's happiness in marriage conceals specific social-economic relations which are structured in such a way that for most women, even in our affluent society, marriage is a necessity for daily survival. Especially as they advance in age, women would live in poverty without men's wages to support them and the children they might have. ${ }^{5}$ Women, of course, also need the wages they can earn, even if those wages-as it is well known-are much lower than men's. Whether women are hired at all and whether once hired they would be able to keep or be promoted in a job depends, more often than not, on men. It is typically men who interview and make decisions about hiring, firing, and promotion. Most men have been inundated with images of femininity and the working woman, and it is these images whose personification they tend to look for in female employees. (When the interviewers are women, they too are likely to make decisions on the basis of the masculine image of femininity and the working woman.) A working woman, according to the popular images, is white, young, thin, fashionably dressed and made up, who smiles or looks pensive depending on what the situation demands.

\section{Being Thin}

The theme of anxiety about achieving an attractive appearance emerges consistently when women speak of their relentless pursuit of thinness. ${ }^{6}$ Thinness, as a major component of the contemporary ideal of attractive appearance, and women's future seem inextricably intertwined. A woman is never "good," never quite acceptable the way she is; she must always stand out, be "number one" in something. Ideally, however, a woman should be number one in everything. No matter how outstanding a woman might be in a specific area of work, for instance, no achievement is a true substitute for attractiveness; she must still attempt to make herself attractive. If she does not do so, she will be considered not feminine, she will be a threat to men. ${ }^{7}$ Furthermore, she will not be viewed as healthy unless she is fashionably thin and youthful looking. Being fat is taken as a sign of inadequacy, incompetence, or psychological problems- 
In a sense, it is our physical appearance that others see first. For me, in my job, people come to see me, and get an immediate impression. I don't want my body to interfere with what I can offer...

Being overweight is often taken as a lack of control. "Well, gee, that person's sure got a problem!" That's how I think about people who are largely overweight. Very critically. You mean, I mean, it's obvious because there isn't a medical problem in the majority of situations, they just eat too much. ${ }^{8}$

As this quote suggests, being seen as overweight is not only an obstacle in performing a job, it is also perceived as a sign of psychological problems (lack of self-control). In this society, many women come to view themselves as inevitable failures and objects of hate and rejection if they are not thin or at least losing weight. One woman, describing her 20-year struggle to be thin, stated that she hated herself when she was fat and was in love with herself when she was thin. A woman who had been regarded overweight from age 5 to 18 said, "Who would want a fat date, let alone marry one?" Loneliness, isolation, and pretended cheerfulness to secure some companionship were among the possibilities she had to look forward to if she did not lose weight and stay slim. Another woman was turned away from a party just because she was not deemed attractively thin. Yet another woman remarked that she was afraid that if she continued gaining weight no man would want her even for sex, and what would her life become without the possible love of a man? ${ }^{9}$

At least in North American society by the time girls reach their teens or even earlier, they know they have to "look good." This means, among other things, that they must do everything possible to avoid being fat, to have fair, clear skin, and the right words for boys to be popular and to have dates. A woman recalled her midteens, when she began to be aware of having to look good, as follows:

I was starting to become more aware of my appearance. Instead of just doing sports for sports sake I was exercising to look good. I wanted to be noticed by the boys.... I was reading books on how to be popular with boys, how to look good. And, of course, my mother was buying these books on the menstrual cycle and they tell you how to take care of yourself, use deodorant, brush your teeth, wash your hair.

I remember reading that girls should let boys do all the talking. Smile and say nice things to a boy, cliché things like "Michael, what big muscles you have!"... I was supposed to sit and smile at everything he said, and never be bored and look bored... The real objective was to be the prettiest girl, the competition is tough, you've got to dress nice, you've got to wear make-up, you know, make yourself the best you can be. ${ }^{10}$

Numerous women have attended so-called finishing schools to learn about and polish the manner in which they ought to present 
themselves. They have read countless books and magazine articles on the subject and watched experts on television showing them how to do their hair and enhance their appearance in general. More recently, women have been attending gyms and so-called health clubs-if they can afford them-in the name of "getting fit." Fitness, however, is not the primary motivation here; it is a means to an end. Health clubs are recommended as "very good places for singles to meet because they start out with so much in common."11 As the title of the article from which the quotation is taken suggests, for women fitness is also about potential romance. A new criterion has been attached to the promised fulfillment of fantasies of love and happiness: fitness. This means, of course, that women now also need to purchase, in addition to the gym or club membership, the outfits appropriate to the workout. Women's sports and gym wear has become a salesmen's paradise in North America, extending the list of every artificial thing women have been made to purchase to overcome the insecurities that have been instilled in them and to make them look young and attractive to men. ${ }^{12}$ In exchange for their purchases women have been promised a life-style on a man's side that would ensure their happiness if they continued to consume. Although fitness and thinness in popular ideology have been associated with health, it is all too obvious that the fundamental equation is with attractiveness and sexuality ${ }^{13}$ and, most profoundly, with the political economics of women's survival. ${ }^{14}$

Even the few examples offered in this paper illustrate that women must make themselves desirable in order to attract and keep the right man. Marriage is both a necessity for most women to survive and it has been constructed as the utmost object of female desire. Most women also want to be married. A recent study released on $\mathrm{Ca}$ nadian adolescent girls' expectations concerning their future lives found that three-fourths of the interviewed girls anticipated marriage, and most of them dreamt of husbands in well-paying professions..$^{15}$ The results of this survey suggest that young girls and women in Canada today still see themselves as primarily wives and mothers, caretakers in the home, dependent on the better wages of men. This may well be women's reality for the decades to come. The irony of this situation is that whereas young girls seem to look forward to this future, it is this future which, almost inevitably, entraps them in, and perpetuates, their situation of being dominated, exploited and objectified.

\section{Temporality and Appearance}

When women pose the question, "am I attractive?" they are also asking, "what I am to do to make myself more attractive?" Attractive appearance is produced; it is work women spend their hours, days, and years performing. Women need to spend time and a lot of money learning about the "what" and "how" of an idealized version 
of femininity. Entire industries depend on women's investment in the purchase of attractive appearance. For some women, the pursuit of attractiveness overtakes their lives. For the women who have carried the concern with attractiveness (thinness) beyond what, in everyday terms, is referred to as "reasonable" limits, exercising and food-related activities fill nearly all their waking hours. As one of them noted, she simply had "no time for anything else."16 Obviously, when some women spend their time continually trying to perfect their appearance, they are not doing other things, not developing other interests, not asking about their situations, not reflecting on "why do I have to be attractive?" not looking beyond their immediate surroundings and broadening their horizons. What is not related to the work of beautification falls outside the domain of what is perceived and acted on, and thus women's confinement in a narrow range of concerns and activities is perpetuated. When perfecting their appearance is the major work many women must engage in, they live toward a tomorrow that never comes. It never could come, because that tomorrow is a fantasy. Women's living present, then, is an existence in suspense, in a posture of anxious anticipation. Yet all the other activities not pursued while women attempt to produce themselves as attractive are, paradoxically, an attempt to "have a future"-through men and marriage and (under)paid work to survive.

In the pursuit of attractive appearance, the body can be viewed as the road that maps women's future territory. The body is the means through which a particular promise of the future is being sustained. It is the body's appearance that is believed to secure the husband, the means of livelihood, and, on a relative scale, the glamour depicted in the commercial media. It is the body that, women are told, would help them "move up" in the world: Through her association (preferably marriage) with a man she may find the opportunity to avoid at least some of the oppressive aspects of her current situation. Women's pursuit of attractive appearance reveals that who a woman is and the kind of future that may be a possibility for her depends on her body's appearance relative to how her body compares to a contemporary ideal.

How the body maps women's future territory is well exemplified by the beauty contests. The winner is presented as the concrete fulfillment of the ultimate promises made to women: promises of admiration, fame, and a life-style of luxury. These contests are a dream come true-for the woman who has been produced as the most beautiful. The intended reading of these contests is that "you too could be one of them." The beautiful women in the 1986 mother/ daughter pageant were portrayed as having it all: wealth, beauty, talent, men's admiration. Through being deemed beautiful, they could be and have; they could be objects of desire and have the material goods of a particular life-style. Their major work in life was the 
production of their appearance as desirable to men but, in the beauty contests, not even a hint was offered to the effect that such a project may be detrimental to women.

Yet the body in the pursuit of attractive appearance is constantly experienced as a threat in that the body's ability to approximate the ideal (which is the pivot of the promised possibilities) will be eroded and, hence, the future will disintegrate. When women strive to produce themselves as attractive, the present is a present lived toward the future: when the promises of romantic love and happiness, success and approval will be fulfilled. The present cannot be enjoyed; even the simplest pleasures are causes for worry. The food consumed now will show weight gain tomorrow; the time spent napping or strolling casually is time not devoted to rigorous exercise, to "toning the muscles." Anxiety, guilt, and a sense of failure are characteristic ways many women experience such and similar situations, situations that most men would thoroughly enjoy, or at least take for granted. Women's experience in the present is typically one of "not yet"; she is not yet attractive (enough). She must try harder, do more, work on perfecting her looks, herself. She reinterprets the past in terms of how the body she had fares in relation to current ideals of attractiveness; her present pursuit of attractiveness is horizoned by her living ambivalently both her past and her future.

The future is lived ambivalently: She will either have all of the promises fulfilled, or she will have nothing and be nobody. The bathroom scale is the immediate gauge of her future; the pounds that have been lost and remain to be lost announce the present's distance from the future. This future, at the same time, is a continual threat, for she may not be able to keep losing weight; age spots, stretch marks, and wrinkles will begin to appear on her skin. These signs announce the shrinking and possible loss of territories-territories that have never been possessed. The future cannot ever be fully realized because it is bound up with a particular ideal of attractiveness. This ideal has never been lived (by anyone), and the body's ability to approximate it keeps eroding as women grow older.

In the pursuit of attractive appearance the relationship to the past is also lived ambivalently because the past is when she may have been "fat and ugly," when the body's appearance was one that must never be true of her again. In our media-dominated, capitalist, patriarchal society, anything connected to the "fat me"-defined in terms of contemporary beauty standards-is "not me" and must be denied. The period in a woman's life before she lost weight is a time that must be forgotten and totally disowned. Many women succeed in denying that past; they can speak of themselves at 20 or 100 pounds more than their present weight as if they were speaking of another person, a total stranger with whom they have no ties; that "me," after all, is "not me." 
The past, on the other hand, may be when she was thin and pretty. That "me" is now recounted nostalgically; her attractiveness then speaks to the fading of her beauty now. A woman in her late 50s had as her goal to weigh the same 114 pounds that she did 30 years ago, on her wedding day. She was convinced that that was her "real self," as well as who she must be in the future. Now, however, she was neither the fat and ugly me, for she had lost some weight, nor the thin and pretty me she once was. Even if one day the scale showed the 114 pounds, never again would she be the woman she was 30 years ago. Women much younger than her have spoken similarly about themselves. For these women, because the past is either about who they once were but must never be again or who they once were but are no longer, the present is a suspended instant, a living in the past that is "not me" now and a living toward the future they both dread and, some of them realize, they can never fully have.

In light of the above characterization of many North American women's lived time, the question arises: In what sense can we speak of women's identity? What is women's identity? Is it different from men's, and if so, how? How does it develop? Fundamentally, the question is, "How and through what psychological processes does that special 'being,' that particular 'objectivity,' the finite and contingent individual existence that we call social being or personality become identical with oneself?"17 Although the scope of this question exceeds by far the present paper's framework, based on the explication of women's anxious pursuit of attractive appearance in North America today, it is possible to sketch at least a few aspects of women's identity. These points are relevant to the social aspects of identity, that is, to one of the two foci of the identity system. ${ }^{18}$ No attempt is made here to comment on personal identity, whose basis and experiential framework is the individual's biography. ${ }^{19}$

Identity, or sameness with oneself, presupposes continuity. Women's anxious pursuit of attractive appearance, however, reveals disjunctions between past, present, and future. The past has to be denied, the present cannot be lived/enjoyed, and the future-which is the idealized future of desire-can never be had. Because women's existence is defined by the possibilities the body's appearance projects, subjectivity is lived as a series of radical separations. Living in this manner, women cannot be grounded in experiences that may deliver them toward a future in which the transformation of their situations becomes a realistic aspiration.

\section{Spatiality and Appearance}

From a spatial perspective, women's identity emerges as a constriction. Women's lived world is a set of tight and narrow spheres. These spheres have been demarcated by men for women (kitchen, bedroom, and the lowest paying jobs). Even the immediate vicinity of their bodies is experienced by women as not their own. Women 
cannot claim space; the very space a woman's body occupies is a space of potential violence. Women's attempt to break out of their spatial confinements is always at the risk of losing the margin of security and safety (however tenuous it is) they may have had. If women try to appropriate masculine styles of being in the world, they are charged with being competitive, aggressive, or arrogant, in short "not feminine." They become a threat to male power. If women use their feminity to gain access to spaces that have been occupied by men, they are open to criticisms of having no brains. If women do not succeed in traditionally male spheres of life, it becomes their fault. It is so because they are said to be suffering from an incurable psychological condition, the so-called "inferiority complex"-inferior, of course, to men. The women who have hoped to break out of certain oppressive situations by the pursuit of attractive appearance have often done so at the cost of destroying their bodies, their lives. This happened, supposedly, because they let themselves be carried away; they were not reasonable or rational in their pursuits.

A woman's self (or social identity), as Simone de Beauvoir points out, is constituted as Other:

She is defined and differentiated with reference to man and not with reference to her; she is incidental, the inessential as opposed to the essential. He is the Subject, he is Absolute-she is the Other. ${ }^{20}$

Woman's identity as Other, however, is not an eternal and irrevocable essence of woman. Or, as Smith argues, it is not "a universal characteristic of the relations of men to women and women to men;" rather, these relations are "specific to a given class in a given kind of society." 21 The particular contents and forms of women's identity as Other are contingent on the social relations in contemporary North American corporate capitalism.

In today's North American society, women's identity can only be described with reference to men. North American women exist in a male defined and male dominated world, a world in which most of them can survive only through having to depend on men-for money, jobs, and assumed or actual protection from other men. In this world, the chief source of a woman's power is her body and her ability to produce it as feminine in accordance with the male view of attractiveness for women. But, as we have seen, the same body is both a woman's means of survival and the site of her oppression and domination. Women's motivation for using the body as "currency in the male realm," to carve out spaces for existence, is to avoid poverty and its concomitant abuses and violence. In search of some safety and security, however, women must participate in their own objectification. Many women become so alienated from their bodies that they can only refer to themselves as an "it;" "it" is fat or disproportionate or otherwise unattractive. In the pursuit of attractive 
appearance, self and body become split; the body transforms into an out-of-control, unruly, ugly thing, the self becomes a web of hatred, disgust, and reproach.

The anxiety women experience about their appearance points to a set of issues of which the psychological is only one dimension. In contemporary North America, women are almost doomed to experience their identity and world in an anxious manner. This is, fundamentally, a social-political issue and, hence, of concern to all spheres of education. Whenever they can be found, openings should be sought to interrupt the invitation for the practices of the pursuit of attractive appearance, practices which are many women's primary means to have a future. Women's identity is not Other by nature; it is Other by socially constructed necessity, but not inevitability.

\section{Notes}

1. For explication of existential anxiety, see Kierkegaard, S. The concept of dread. Princeton: Princeton University Press, 1974; Heidegger, M. Being and time. New York: Harper \& Row, 1962; Boss, M. Anxiety, guilt and psychotherapeutic liberation. Review of existential psychology and psychiatry, 1962, 3, 173-195; Sartre, J.P. Being and nothingness. New York: Pocket Books, 1972; Johnson, R.E. Existential man: The challenge of psychotherapy. New York: Pergamon, 1971. Also see Fischer, W. Theories of anxiety. New York: Harper \& Row, 1970; Fischer, W. On the phenomenological mode of researching being anxious. Journal of Phenomenological Psychology, 1974, (2), 405-423; Fischer, W. An empirical-phenomenological investigation of being anxious: An example of the meaning of being emotional. In R. Valle and M. King (Eds.), Existential phenomenological alternatives for psychology. New York: Oxford University Press, 1978.

2. Forbes, D. (1985). On the politics of beauty. Borderlines, 3, 29-30.

3. Cassel, C. (1985). Swept away. Toronto: Bantam.

4. Szekely, E. (1986). Filling the void: A sociocultural analysis of the relentless pursuit of thinness among women. Unpublished doctoral dissertation, University of Toronto (OISE).

5. Cohen, L. (1984). Small expectations. Toronto: McClelland and Stuart.

6. Szekely, 1986.

7. Brown, L. (1985). Women, weight and power: Feminist theoretical and therapeutic issues. Women and Therapy, 1,61-71.

8. Szekely, 1986.

9. Examples in this section are from Szekely, 1986 .

10. Szekely, 1986.

11. Horton, M. (1985, August). Health club romances: For the love or the sweat of it? Slimmer.

12. Ewen, S. (1976). Captains of consciousness. Toronto: McGraw-Hill.

13. Coward, R. (1985). Female desire. London: Granada.

14. For a powerful illustration of the connections between attractiveness/sexuality and survival, see El Saadawi, N. (1983). Women at point zero. London: Zed. 
15. Baker, M. (1985). What will tomorrow bring?... A study of the aspirations of adolescent women. Ottawa: Canadian Advisory Council on the Status of Women.

16. Szekely, 1986.

17. Pataki, F. (1986). Identitásviták nyomában. Valóság, 6, 46-63. [Tracing the debates on identity, Reality].

18. Pataki, 1986.

19. Pataki, 1986.

20. de Beauvoir, S. (1961). The second sex. New York: Bantam.

21. Smith, D.E. (1973). Women, the family and corporate capitalism. In M. Stephensen (Ed.), Women in Canada (pp. 1-35). Toronto: New Press. 